\title{
KAJIAN RETROSPEKTIF PENYAKIT DEMAM BERDARAH DENGUE DAN CHIKUNGUNYA DI KOTA TANGERANG DALAM 10 TAHUN (2003-2013)
}

\author{
*Aminah, *Makhabbah Jamilatun
}

\begin{abstract}
Abstrak
Demam Berdarah Dengue (DBD) dan Chikungunya merupakan penyakit viral endemis bersumber nyamuk di Indonesia.Organisasi kesehatan dunia WHO tahun 2009 mengelompokkan demam berdarahmenjadi demam berdarah ringan dan tiga kriteria demam berdarah berat yaitu Demam Dengue (DD), Demam Berdarah Dengue (DBD), dan Sindrom Syok Dengue (SSD)[1]. Data sekunder berupa laporan kasus penyakit yang diterima/ditangani puskesmas dan laporan pemeriksaan laboratorium terkait DBD dan Chikungunya selama sepuluh tahun dikumpulkan dan disajikan secara deskriptif. Penelitian ini merupakan penelitian retrospektif dengan desain eksploratif pada kasusDBD-Chikungunya di Kota Tangerang tahun 2003-2013. Instrumen penelitian yang digunakan berupa buku bantu DBD yang dibuat oleh penanggung jawab Program pemberantasan DBD di Puskesmas Kota Tangerang tahun 2003-2013. Populasi dalam penelitian ini adalah seluruh Puskesmas yang ada di wilayah Kota Tangerang yang berjumlah 32 Puskesmas. Sampel dalam penelitian ini berjumlah tujuh Puskesmas yang terdiri dari dua Puskesmas dengan data lengkap mulai 2003 dan lima Puskesmas dengan data kurang lengkap. Pengumpulan data dilakukan secara langsung peneliti dengan menelaah catatan/data yang ada dalam buku bantu DBD di Puskesmas Kota Tangerang mulai tahun 2003 hingga 2013. Data yang dikumpulkan sesuai dengan variabel yang menjadi fokus penelitian yaitu data tentang kejadian DBD dan Chikungunya baik yang baru suspek maupun yang sudah dikonfirmasi.Data disalin dari buku bantu DBD ke dalam format digital untuk selanjutnya dilakukan pengolahan dan analisis data menggunakan perangkat lunak dalam komputer. Dari hasil analisis yang dilakukan, berikut simpulan yang dapat ditarik: Pencatatan Kasus DBD-Chikungunya di Puskesmas belum tertata dengan baik dan belum seragam. Masih terjadi banyak kasus DBD-Chikungunya yang tercatat di Kota Tangerang. Rata-rata frekuensi DBD-Chikungunya tinggi terjadi pada dua trimester pertama. Perkembangan penyakit DBD-Chikungunya dari tahun ke tahun tidak seragam.
\end{abstract}

Kata Kunci: Demam Berdarah Dengue (DBD), Chikungunya, Kajian Retrospektif

*Dosen Poltekkes Kemenkes Banten 
Pendahuluan

Demam Berdarah Dengue (DBD) dan Chikungunya merupakan penyakit viral endemis bersumber nyamuk di Indonesia.Organisasi kesehatan dunia WHO tahun 2009 mengelompokkan demam berdarah menjadi demam berdarah ringan dan tiga kriteria demam berdarah berat yaitu Demam Dengue (DD), Demam Berdarah Dengue (DBD), dan Sindrom Syok Dengue (SSD)[1]. Berbagai kajian retrospektif telah mengungkap hubungan antara iklim dan penularan DBD. Gabungan data pola spasio-temporal epidemic DBD dan perubahan iklim serta sosioekologi jangka panjang dapat memprediksi/mendeteksi dini risiko demam berdarah [2].

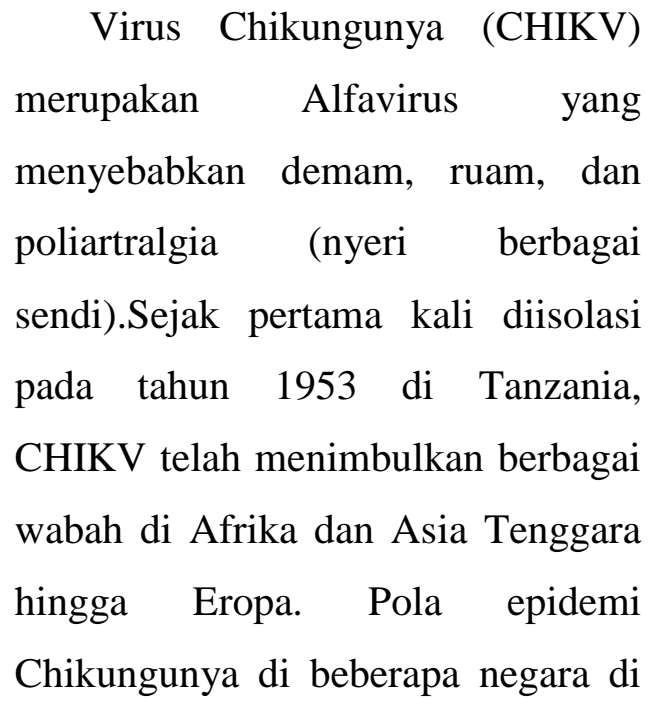

dunia menunjukkan beredarnya CHIKV mutan [3].Hal ini tidak menutup kemungkinan bahwa CHIKV yang tersebar di Indonesia memiliki perbedaan di setiap daerah.Demam Chikungunya melibatkan infeksi virus sistemik yang bersifat self-limiting (dapat hilang dengan sendirinya). Beberapa tahun terakhir gejala pada mata lebih sering muncul dan hingga saat ini belum ada vaksin maupun obat spesifik untuk mencegah dan mengobati Chikungunya [4]. Oleh karena itu perlu dilakukan kajian epidemiologi, karakterisasi virus, termasuk manisfestasi klinis, dan pemeriksaan laboratorium yang tepat untuk pengendalian dan pencegahan penyakit secara efektif[5] meskipun beberapa kajian reterospektif telah dilakukan untuk menemukan manifestasi klinis penyakit Chikungunya[6].Kajian retrospektif untuk prediksi/deteksi dini DBD mestinya juga dapat diterapkan pada Chikungunya selamadilakukan terhadap populasi berisiko, melibatkan survey penyakit disertai deskripsi luaran hasilnya, serta didukung oleh data empiris[7]. Dari 
sekian kajian yang harus dilakukan dalam rangka membebaskan masyarakat dari ancaman DB dan Chikungunya, kami akan mengambil langkah awal yang diperlukan dalam lingkup yang terukur.

\section{Metode penelitian}

Metode penelitian yang digunakan

dalam penelitian ini adalah Penelitian Deskriptif. Penelitian ini dilaksanakan di Puskesmas dalam wilayah Kota Tangerang. Penelitian ini terlaksana pada bulan November 2014.

Populasi dalam penelitian ini adalah seluruh Puskesmas yang ada di wilayah Kota Tangerang yang berjumlah 32 Puskesmas.

\section{Hasil Dan Pembahasan}

Sebelas dari 32 Puskesmas di Kota Tangerang telah disurvey untuk memperoleh data sekunder berupa catatan harian kasus DBD, buku bantu, atau buku visum dari Pemegang Program Pemberantasan DBD, empat di antaranya tidak memberikan hasil yang diharapkan. Terbatasnya jumlah Puskesmas yang berhasil disurvey antara lain disebabkan oleh keterbatasan waktu pelaksanaan yang semula direncanakan mulai akhir September namun tertunda hingga awal November karena lambatnya proses pembuatan surat rekomendasi penelitian.

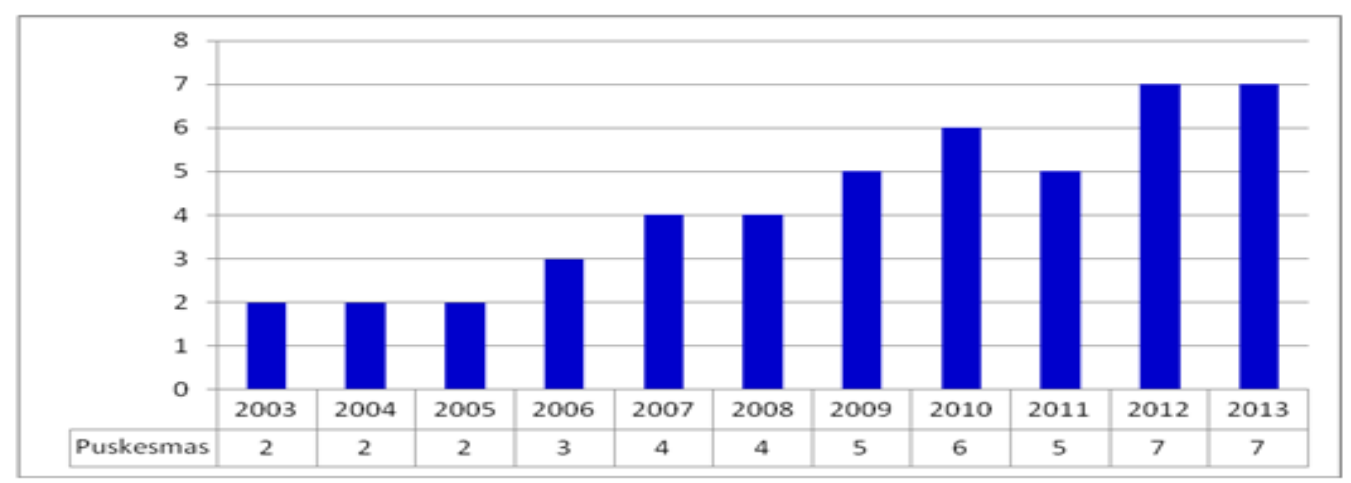

Gambar 1. Jumlah Puskesmas yang Memiliki Data 10 Tahun

menghambat upaya memperoleh data 
sekunder perkembangan penyakit DBD dan Chikungunya selama 10 tahun di Puskesmas Kota Tangerang antara lain: Puskesmas tidak memiliki data lengkap karena baru berdiri atau hasil pemekaran; dokumen hilang/rusak/tidak tersimpan karena pergantian personel atau bencana alam dan kerusakan komputer; tidak tercatat karena belum ada keseragaman pencatatan sebelum tahun 2010; bahkan ada personel yang tidak bersedia memberikan data karena beberapa alasan. Dari tujuh Puskesmas yang datanya dapat diperoleh, hanya dua yang memiliki dokumen lengkap mulai tahun 2003().Jumlah Puskesmas tahun 2011 turun dari sebelumnya karena satu Puskesmas yang tidak bersedia memberikan data lengkap.

Virus Dengue secara endemis ditemukan di daerah-daerah tropis di seluruh dunia namun belum ada obat spesifik maupun vaksin untuk pengobatan dan pencegahannya.Di Indonesia, Sukabumi, hasil survey molekuler menunjukkan tiga serotipe yaitu DENV-1, DENV-2, dan DENV-4 bersirkulasi di lingkungan namun tidak ditemukan serotipe DENV-3 [14], meskipun serotipe DENV-3 merupakan yang terbanyak di Indonesia.Ini menunjukkan penyebaran virus yang tidak merata sehingga kemungkinan terjadi wabah di tempat berbeda menjadi tinggi serta mempengaruhi pola perkembangan penyakit.

Puskesmas sebagai fasilitas pelayanan kesehatan lapis pertama difokuskan pada penanganan sumber penularan penyakit DBD yaitu nyamuk. Dengan demikian virus Chikungunya yang juga bersumber nyamuk dengan gejala awal mirip DBD ikut ditangani oleh Puskesmas dengan cara yang sama meskipun tidak ada Program khusus untuk Chikungunya seperti Program pemberantasan DBD. Beberapa Puskesmas ikut mencatat kasus Chikungunya dalam buku bantu DBD dan tindak lanjut berupa abatisasi maupun fogging dijadikan sebagai bagian dari kegiatan Program pemberantasan DBD. 


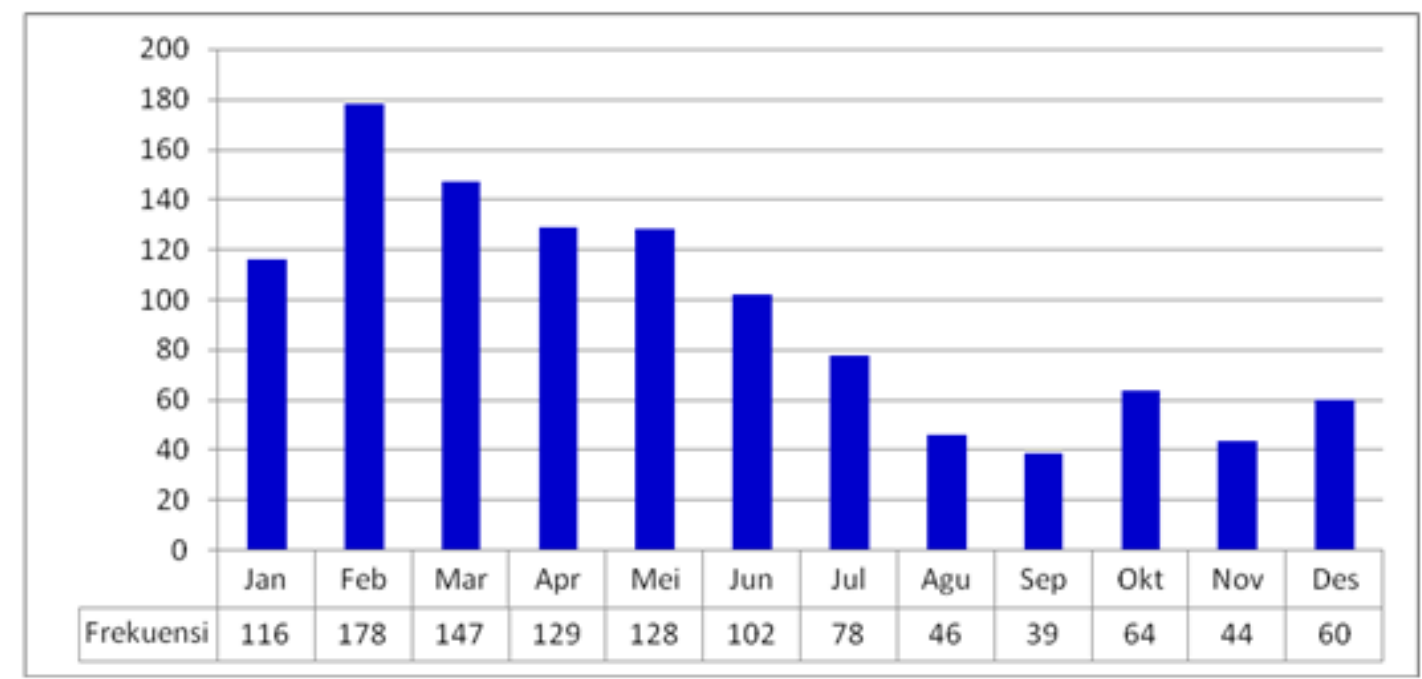

Gambar 2.Frekuensi Kasus DBD-Chikungunya Per-bulan (2003-2013)

Pasien yang datang melaporkan diri atau dilaporkan oleh kader Puskesmas dengan gejala klinis atau disertai hasil pemeriksaan laboratorium dari Rumah Sakit, Klinik, maupun penyedia layanan pemeriksaan laboratorium dicatat dan dalam hal ini dimasukkan kedalam bagian dari perkembangan kasus DBD-Chikungunya.Hasil penjumlahan kasus per-bulan dari tahun ke tahun menunjukkan frekuensi pasien tertinggi terdapat di awal tahun yaitu bulan Februari kemudian berangsur menurun hingga September dan kembali naik hingga Januari (Gambar 2.Frekuensi Kasus DBD-Chikungunya Per-bulan (20032013)Gambar 2). 


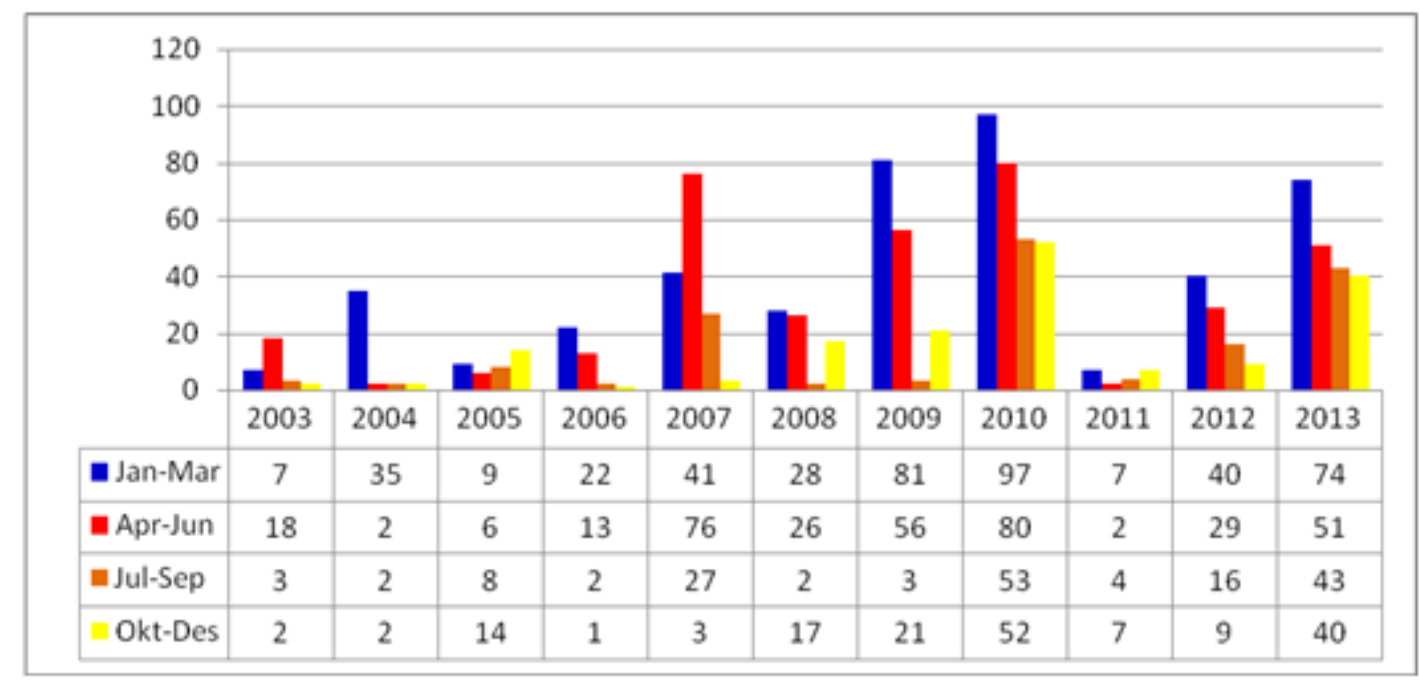

Gambar 3. Frekuensi Kasus DBD-Chikungunya Per-Trimester

Dari Gambar 2 dapat diperkirakan bahwa jika satu tahun dibagi kedalam empat trimester, maka dari tahun ke tahun kasus DBDChikungunya akan sering ditemukan pada trimester pertama dan kedua. Namun bila dilihat data per-tahun ternyata perkembangannya tidak seragam (Gambar 3 dan Gambar 4) meskipun kasus tertinggi tetap terjadi pada trimester pertama dan kedua. Hal ini terjadi karena program pengendalian vektor, pengobatan, pola perpindahan masyarakat dapat mengubah pola perkembangan virus dan vektor virus [10].

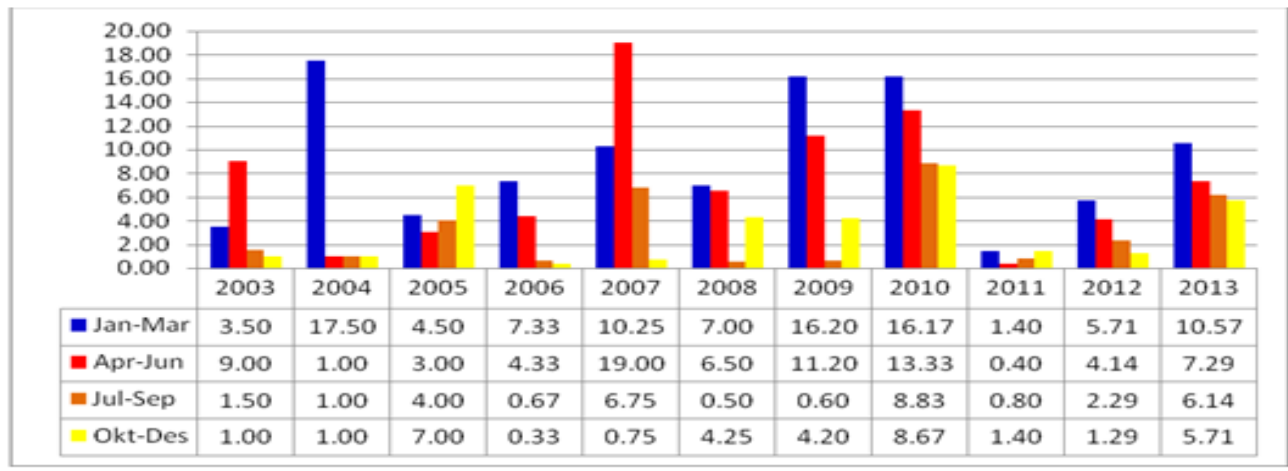

Gambar 4. Rata-rata Kasus DBD-Chikungunya Per-Trimester 
Antara total frekuensi kasus pertrimester dalam 10 tahun dengan rata-rata frekuensi per-Puskesmas tidak terdapat perbedaan yang signifikan (Gambar 4). Hal ini menunjukkan bahwa antar wilayah kerja Puskesmas tidak terdapat perbedaan signifikan dalam upaya pengendalian penyakit DBDChikungunya.

\section{Simpulan}

1. Pencatatan Kasus DBDChikungunya di Puskesmas belum tertata dengan baik dan belum seragam.

2. Masih terjadi banyak kasus DBDChikungunya yang tercatat di Kota Tangerang.

3. Rata-rata frekuensi DBDChikungunya tinggi terjadi pada dua trimester pertama.

4. Perkembangan penyakit DBDChikungunya dari tahun ke tahun tidak seragam.

\section{Daftar Pustaka}

1. Horstick O, Jaenisch T, Martinez E, Kroeger A, See LL, Farrar J, Ranzinger SR. 2014. Comparing the Usefulness of the 1997 and 2009 WHO Dengue Case Classification: A Systematic Literature Review. Am J Trop Med Hyg, 91(3):621634.
2. Naish S, Dale P, Mackenzie JS, McBride J, Mengersen K, Tong S. 2014. Climate change and dengue: a critical and systematic review of quantitative modelling approaches. BMC Infect Dis, 14:167.

3. Jain M, Rai S, Chakravarti A. 2008. Chikungunya: a review. Trop Doct, 38(2):70-72.

4. Mahendradas $\mathrm{P}$, Avadhani K, Shetty R. 2013. Chikungunya and the eye: a review. $J$ Ophthalmic Inflamm Infect, 3(1):35.

5. Staples JE, Breiman RF, Powers AM. 2009. Chikungunya fever: an epidemiological review of a re-emerging infectious disease. Clin Infect Dis, 49(6):942-948.

6. Waymouth HE, Zoutman DE, Towheed TE. 2013. Chikungunya-related arthritis: case report and review of the literature. Semin Arthritis Rheum, 43(2):273-278.

7. Runge-Ranzinger S, McCall PJ, Kroeger A, Horstick O. 2014. Dengue disease surveillance: an updated systematic literature review. Trop Med Int Health, 19(9):1116-1160.

8. Yauch LE, Shresta S. 2014. Dengue virus vaccine development. Adv Virus Res, 88:315-372.

9. Zhang $\mathrm{H}$, Zhou YP, Peng HJ, Zhang XH, Zhou FY, Liu ZH, 
Chen XG. 2014. Predictive Symptoms and Signs of Severe Dengue Disease for Patients with Dengue Fever: A MetaAnalysis. Biomed Res Int, 2014:359308.

10. Nevai AL, Soewono E. 2014. A model for the spatial transmission of dengue with daily movement between villages and a city. Math Med Biol, 31(2):150-178.

11. Queyriaux B, Simon F, Grandadam M, Michel R, Tolou H, Boutin JP. 2008. Clinical burden of chikungunya virus infection. Lancet Infect Dis, 8(1):2-3.

12. Sissoko D, Moendandze A, Malvy D, Giry C, Ezzedine K, Solet JL, Pierre V. 2008. Seroprevalence and risk factors of chikungunya virus infection in Mayotte, Indian Ocean, 20052006: a population-based survey. PLoS One, 3(8):e3066.

13. Simon F, Parola P, Grandadam M, Fourcade S, Oliver M, Brouqui P, Hance P, Kraemer P, Ali Mohamed A, de Lamballerie $\mathrm{X}$ et al. 2007. Chikungunya infection: an emerging rheumatism among travelers returned from Indian Ocean islands. Report of 47 cases. Medicine (Baltimore), 86(3):123-137.
14. Nusa R, Prasetyowati H, Meutiawati F, Yohan B, Trimarsanto H, Setianingsih TY, Sasmono RT. 2014. Molecular surveillance of Dengue in Sukabumi, West Java province, Indonesia. J Infect Dev Ctries, 8(6):733-741 
